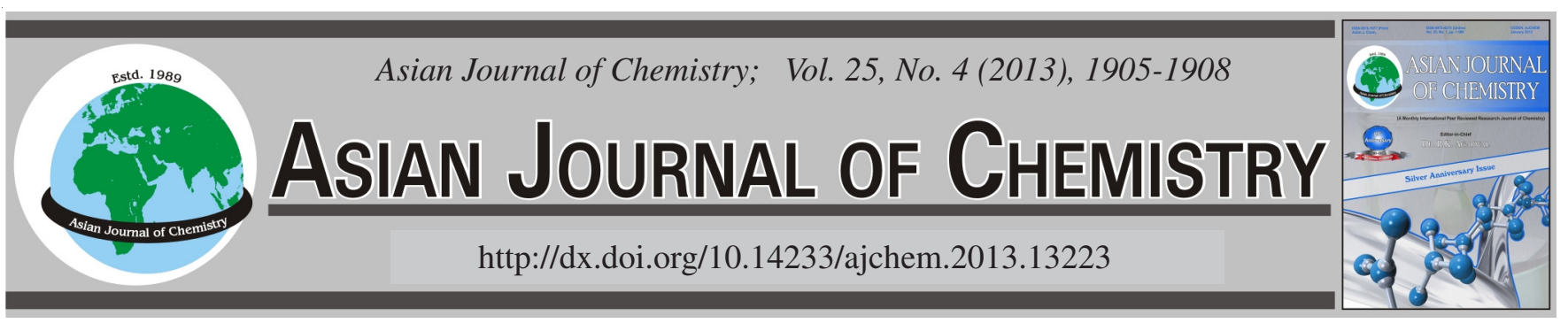

\title{
Adsorption of Dye Olive BGL Using Two Different Samples of Activated Carbon by Static Batch Method
}

\author{
RITA KANT
}

University Institute of Fashion Technology, Panjab University, Chandigarh-160 014, India

Corresponding author: E-mail: rita_kant@yahoo.com

(Received: 10 December 2011;

Accepted: 8 October 2012)

AJC-12247

\begin{abstract}
The removal of dye olive BGL using two different samples of activated carbon by static batch method was studied. Experimental data on optical density of blank solutions of different concentrations ranging from 10-100 mg/L and optical density of solutions after adsorption on activated carbon samples were taken and analyzed. Calibration curves were plotted and the amount of dye adsorbed was calculated. The data was fitted to Langmuir and Freundlich isotherms for two different carbon samples and different concentration values. Constants were calculated from the slope and intercept values of the isotherms. Coefficient of correlation $\mathrm{R}^{2}$ and standard deviation were also recorded. The data fitted well to the isotherms. Carbon sample $\mathrm{C}_{1}$ showed higher potential to adsorb the dye olive BGL at lower concentrations of the solution whereas carbon sample $\mathrm{C}_{2}$ showed better results at higher concentration. Carbon sample $\mathrm{C}_{2}$ showed better adsorption in acidic $\mathrm{pH}$ as compared to in alkaline $\mathrm{pH}$. From the analysis of the data it is shown that activated carbon has good capacity to remove the textile dye from the residue water.
\end{abstract}

Key Words: Adsorption, Olive BGL, Activated carbon, Textile industry effluent.

\section{INTRODUCTION}

The textile industry is using several thousands of quantities of dyes and chemicals in various processes of textile manufacture including dyeing and printing all of which require large quantities of water. Water consumption for dyeing varies from $30-50 \mathrm{~L} / \mathrm{kg}$ of cloth depending on the type of dye used. An average sized textile mill has a production of about $8000 \mathrm{Kg}$ of fabric per day. It may use as much as ca. 1.6 million liters of water $16 \%$ of which may be consumed in dyeing and $8 \%$ in printing. Dyeing section itself contributes to $15-20 \%$ of the total waste water flow ${ }^{1}$. Use of synthetic dyes has been seen to have a toxic nature and causes an adverse effect on all forms of life. Presence of sulphur, naphthol, vat dyes, nitrates, acetic acid, soaps, enzymes chromium compounds and heavy metals like copper, arsenic, lead, cadmium, mercury, nickel and cobalt and certain auxiliary chemicals all collectively make the textile effluent highly toxic. Other harmful chemicals present in the water may be formaldehyde based dye fixing agents, chlorinated stain removers, hydrocarbon based softeners, non biodegradable dyeing chemicals. These organic materials react with many disinfectants especially chlorine and form by products that are often carcinogenic and therefore undesirable. Many of these also show allergic reactions ${ }^{2}$.

The colloidal matter present along with colors and oily scum increases the turbidity, gives the water a bad appearance and foul smell and prevents the penetration of sunlight necessary for the process of photosynthesis. This in turn interferes with the oxygen transfer mechanism at air water interface which in turn interferes with marine life and self purification process of water. This effluent if allowed to flow in the fields' clogs the pores of the soil resulting in loss of soil productivity. If allowed to flow in drains and rivers it effects the quality of drinking water in hand pumps making it unfit for human consumption $^{3-6}$. It is important to remove these pollutants from the waste waters before their final disposal.

The commercial granular activated carbon for adsorption of dyes from aqueous solutions and observed that the adsorption data could be explained by Freundlich isotherms ${ }^{7}$. The adsorption at a given concentration decreased with increase in temperature although the rate of adsorption increased with increase in temperature. Addition of sodium chloride increased the adsorption rate and lengthened the breakthrough time. It was found that direct dyes did not adsorb as readily as other dyes.

Pathe et al. ${ }^{8}$ studied the treatment of textile waste water by physiochemical methods. It was pointed out that the major components in dyeing waste waters are dyes, surfactants, starch, chemical aids and suspended solids. Dyes are divided into hydrophilic and hydrophobic compounds. The former are removed effectively by activated carbon and chlorine while 
the later are removed by floatation. Starch is removed by flocculation. A treatment scheme was designed using the unit process of floatation, flocculation-settlement, sand filter and activated carbon. Results showed that water from cotton dyeing and processing unit when treated as above could be reused as effectively as river water.

In the present work, experiments were conducted on olive BGL $\left(\mathrm{C}_{19} \mathrm{H}_{18} \mathrm{~N}_{4} \mathrm{O}_{5} \mathrm{~S}\right)$ which is an acidic dye used for dyeing wool and silk. It is also called acid black 64 and belongs to 1:2 metal complex dye.

\section{EXPERIMENTAL}

Static batch method: Samples of granular activated carbon $\mathrm{C}_{1}$ and $\mathrm{C}_{2}$ used were obtained from Brillex Chemical Ltd. Punjab and Industrial Carbon Pvt. Ltd., Gujarat. Surface area of $\mathrm{GAC} \mathrm{C}_{1}$ used in the study was $950 \mathrm{~m}^{2} / \mathrm{g}$ and that of $\mathrm{GAC} \mathrm{C}_{2}$ was $600 \mathrm{~m}^{2} / \mathrm{g}$. Bulk density of the two was 500-550 and $600-1000 \mathrm{~g} / \mathrm{L}$, respectively. The ash content was $6 \%$ in $\mathrm{C}_{1}$ and $5 \%$ in $\mathrm{C}_{2}$.

A stock solution of the dyes with a concentration of 1000 ppm was prepared and dilutions were made with distilled water to make different concentrations. Optical density of all the solutions was measured on a spectrophotometer (ELICO make, wavelength range $200-900 \mathrm{~nm}$ ). One gram of activated carbon was placed in each $50 \mathrm{~mL}$ solution of $10-100 \mathrm{ppm}$. The solutions were shaken and kept in a thermostat for $24 \mathrm{~h}$. The samples were then filtered and analyzed spectrophotometrically.

The experimental data for the dyes studied was fitted to Langmuir and Freundlich isotherms. Isotherms represent the relationship between the amount adsorbed and the concentration at a constant temperature. They also provide useful information about the adsorption process and enable determination of useful surface parameters such as surface area, pore size distribution and pore volume of the adsorbant. Each individual type of activated carbon has its own isotherm curve and breaking point characteristics that help to give an estimate of its adsorptive life.

The experimental data was fitted to linear form of Langmuir isotherm for all the $\mathrm{pH}$ values of the dye and for the two samples of granulated activated carbon. The data was fitted to the equation of the type:

$$
\frac{1}{q_{e}}=\frac{1}{Q}+\frac{1}{b Q} \frac{1}{C_{e}}
$$

$\mathrm{q}_{\mathrm{e}}$ indicates the amount of dye adsorbed per unit weight of adsorbent $(\mathrm{mg} / \mathrm{g}) . \mathrm{C}_{\mathrm{e}}$ is the equilibrium concentration of dye in $\mathrm{mg} / \mathrm{L}$. $\mathrm{Q}$ and $\mathrm{b}$ are the Langmuir constants where $\mathrm{Q}$ indicates the adsorption capacity in $\mathrm{mg} / \mathrm{g}$ and $\mathrm{b}$ relates to the energy of adsorption $(\mathrm{L} / \mathrm{mg})$ in different experimental conditions. These were calculated from the straight line slope and intercept of linear plot between $1 / \mathrm{q}_{\mathrm{e}}$ and $1 / \mathrm{C}_{\mathrm{e}}$.

The essential characteristics of Langmuir equation were expressed in terms of a dimensionless separation factor $\mathrm{R}_{\mathrm{L}}{ }^{10}$ :

$$
\mathrm{R}_{\mathrm{L}}=\frac{1}{1+\mathrm{bC}_{0}}
$$

$R_{L}$ values indicate the shape of the isotherm. Value of $R_{L}$ between 0 and 1 indicate a favorable adsorption ${ }^{11} R_{L}>1$ is unfavorable. $\mathrm{R}_{\mathrm{L}}=1$ is linear. $0>\mathrm{R}_{\mathrm{L}}<1$ is favourable. $\mathrm{R}_{\mathrm{L}}=0$ is irreversible.

Langmuir theory is that sorption takes place at specific homogeneous sites within the adsorbent. It is assumed that once a dye molecule occupies a site no further adsorption can take place at that site and theoretically a saturation value is reached beyond which no further adsorption can take place.

Linear forms of Freundlich isotherms were plotted for all the $\mathrm{pH}$ values of the three dyes and for the two samples of granulated activated carbon. The data was fitted to the equation:

$$
\log \mathrm{q}_{\mathrm{e}}=\log \mathrm{K}_{\mathrm{F}}+\frac{1}{\mathrm{n}} \log \mathrm{C}_{\mathrm{e}}
$$

Freundlich constants $\mathrm{K}_{\mathrm{F}}$ and $\mathrm{n}$ were calculated from the slope and intercept of $\log \mathrm{q}_{\mathrm{e}}$ and $\log \mathrm{C}_{\mathrm{e}}$ along with $\mathrm{R}^{2}$ and SD. $\mathrm{K}_{\mathrm{F}}$ (parameter relative to adsorption capacity) and $\mathrm{n}$ (process intensity) were calculated. The value of $\mathrm{n}$ between 2 and 10 indicates good adsorption ${ }^{12}$. Freundlich isotherm is based on heterogeneous surface of adsorbent. The difference in adsorption capacity comes from different molecular structures of dyes and their different molecular weights.

Effect of initial dye concentration: Table-1 and Fig. 1 show the amount $\mathrm{q}_{\mathrm{e}}$ of olive BGL adsorbed by $\mathrm{C}_{1}$ and $\mathrm{C}_{2}$ samples of granulated activated carbon at various ppm concentrations. It can be seen that $\mathrm{q}_{\mathrm{e}}$ on granulated activated carbon $\mathrm{C}_{1}$ and $\mathrm{C}_{2}$ was higher at lower ppm concentration as compared to the adsorption at higher ppm concentration with the adsorbent dose being kept constant for all dye. At $10 \mathrm{ppm}$ concentration and initial $\mathrm{pH}$ of $6.60 \mathrm{C}_{1}$ adsorbed $68 \mathrm{mg} / \mathrm{L}$ of the dye olive GBL and $\mathrm{C}_{2}$ adsorbed $39 \mathrm{mg} / \mathrm{L}$. At $100 \mathrm{ppm}$ concentration the adsorption of the dye was $29.40,33.7 \mathrm{mg} / \mathrm{L}$ on $\mathrm{C}_{1}$ and $\mathrm{C}_{2}$, respectively at the same $\mathrm{pH}$. Thus higher adsorption at lower ppm concentrations was observed.

Effect of pH: Adsorption of olive BGL on granulated activated carbon $\mathrm{C}_{2}$ was greatly affected by change in $\mathrm{pH}$ of the aqueous solution as can be seen in Table-1 and Fig. 1. Amount of dye adsorbed $\mathrm{q}_{\mathrm{e}}$ on $\mathrm{C}_{2}$ in acidic $\mathrm{pH}$ is higher at all ppm concentrations as compared to adsorption in a lesser acidic and an alkaline environment. At an acidic $\mathrm{pH}$ of 3.32 at 10 ppm concentration $\mathrm{C}_{2}$ adsorbed $57 \mathrm{mg} / \mathrm{L}$ of the dye olive BGL. In an alkaline $\mathrm{pH}$ of 9.97 the same $\mathrm{C}_{2}$ adsorbed only $33.5 \mathrm{mg} / \mathrm{L}$ of the dye leaving behind a good number of free adsorption sites on the adsorbent.

TABLE-1

AMOUNT OF DYE OLIVE BGL ADSORBED BY ACTIVATED CARBON SAMPLES $\mathrm{C}_{1}$ AND $_{2}$ AT DIFFERENT $\mathrm{pH}$ VALUES

\begin{tabular}{ccccc}
\hline \multirow{3}{*}{ Dye name } & \multicolumn{4}{c}{ Olive GBL $\mathrm{pH}$} \\
\cline { 2 - 5 } & $\mathrm{C}_{1}$ & $\mathrm{C}_{2}$ & $\mathrm{C}_{2}$ & $\mathrm{C}_{2}$ \\
\cline { 2 - 5 } & 6.60 & 6.60 & 3.32 & 9.97 \\
\hline $\mathrm{C}_{\mathrm{e}}(\mathrm{mg} / \mathrm{L})$ & $\mathrm{q}_{\mathrm{e}}$ & $\mathrm{q}_{\mathrm{e}}$ & $\mathrm{q}_{\mathrm{e}}$ & $\mathrm{q}_{\mathrm{e}}$ \\
\hline 10 & 6.800 & 3.900 & 5.700 & 3.350 \\
20 & 9.800 & 6.700 & 9.390 & 4.800 \\
30 & 12.930 & 10.000 & 12.400 & 6.200 \\
40 & 16.910 & 14.200 & 16.000 & 7.330 \\
50 & 19.590 & 18.400 & 20.000 & 8.950 \\
60 & 21.690 & 22.090 & 23.480 & 10.100 \\
70 & 23.930 & 25.500 & 28.000 & 11.200 \\
80 & 26.600 & 28.870 & 32.260 & 12.500 \\
90 & 28.600 & 32.350 & 34.960 & 12.900 \\
100 & 29.400 & 33.700 & 36.800 & 13.300 \\
\hline
\end{tabular}




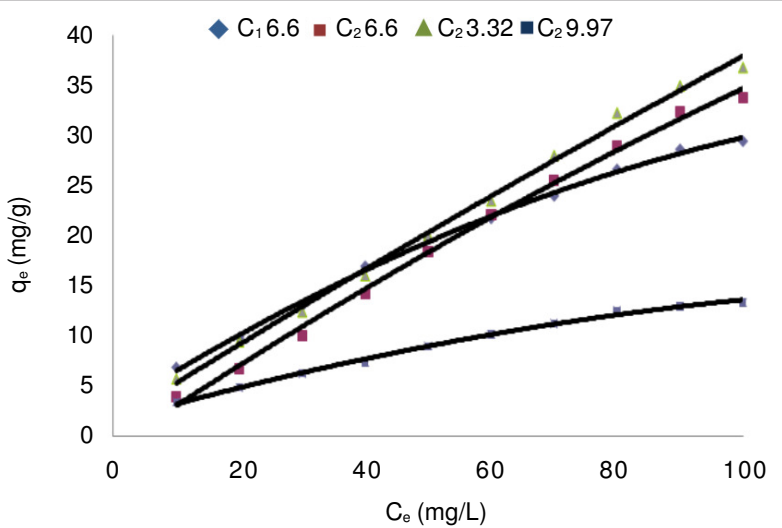

Fig. 1. Adsorption isotherm for dye plive BGL on $\mathrm{C}_{1}$ and $\mathrm{C}_{2}$ at different $\mathrm{pH}$ values

Table-2 gives the values of Langmuir constants $\mathrm{Q}$ and $\mathrm{b}$ along with the values of $\mathrm{r}^{2}, \mathrm{R}_{\mathrm{L}}$ and $\mathrm{SD}$ for dye olive BGL and at varied $\mathrm{pH}$ values and for the two samples of granulated activated carbon, $\mathrm{C}_{1}$ and $\mathrm{C}_{2}$. $\mathrm{R}_{\mathrm{L}}$ values indicate the shape of the isotherm. Value of $R_{L}$ between 0 and one indicate a favourable adsorption Values of constants $\mathrm{Q} b$ also signify good adsorption of the dye on $\mathrm{C}_{1}$.

\begin{tabular}{ccccc} 
& \multicolumn{5}{c}{ TABLE-2 } \\
& $\begin{array}{c}\text { RESULTS FROM FITTINGS TO LANGMUIR } \\
\text { ISOTHERM FOR DYE OLIVE BGL }\end{array}$ \\
\hline \multirow{4}{*}{ Dye name } & \multicolumn{4}{c}{ Olive GBL $\mathrm{pH}$} \\
\cline { 2 - 5 } & $\mathrm{C}_{1}$ & $\mathrm{C}_{2}$ & $\mathrm{C}_{2}$ & $\mathrm{C}_{2}$ \\
\cline { 2 - 5 } & 6.60 & 6.60 & 3.32 & 9.97 \\
\hline $\mathrm{Q}$ & 40.258 & 175.439 & 62.035 & 16.132 \\
$\mathrm{~b}$ & 0.019 & 0.002 & 0.010 & 0.025 \\
$\mathrm{r}^{2}$ & 0.958 & 0.982 & 0.875 & 0.967 \\
$\mathrm{SD}$ & 0.008 & 0.011 & 0.008 & 0.014 \\
$\mathrm{R}_{\mathrm{L}}$ & 0.008 & 0.004 & 0.006 & 0.004 \\
\hline
\end{tabular}

The linear plots of $1 / \mathrm{q}_{\mathrm{e}}$ and $1 / \mathrm{C}_{\mathrm{e}}$ for Langmuir isotherm are shown in Fig. 2.

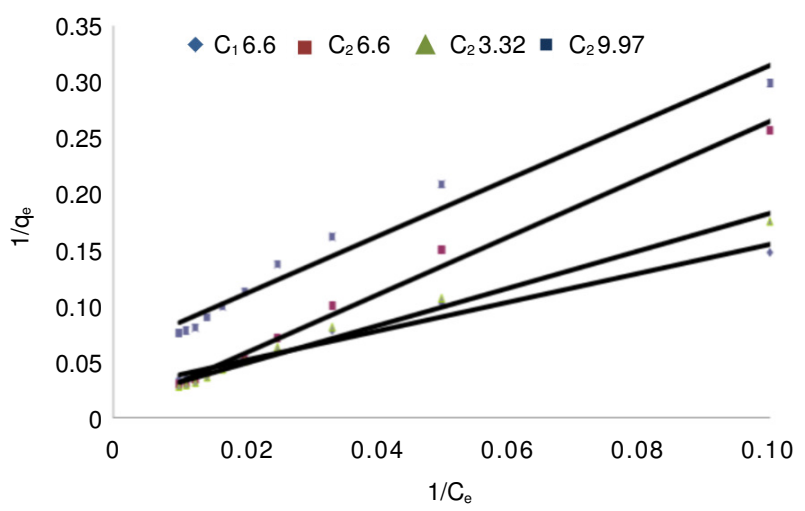

Fig. 2. Langmuir isotherm for dye olive BGL on $\mathrm{C}_{1}$ and $\mathrm{C}_{2}$ at different $\mathrm{pH}$ values

Tables- 3 shows the Freundlich constants $\mathrm{K}_{\mathrm{F}}$ and $\mathrm{n}$ calculated from the slope and intercept of $\log \mathrm{q}_{\mathrm{e}}$ and $\log \mathrm{C}_{\mathrm{e}}$ along with $\mathrm{R}^{2}$ and SD. $\mathrm{K}_{\mathrm{F}}$ (parameter relative to adsorption capacity) and $\mathrm{n}$ (process intensity) were calculated. Values of constant $\mathrm{K}_{\mathrm{F}}$ indicate higher adsorption capacity on carbon sample $\mathrm{C}_{1}$ as compared to $\mathrm{C}_{2}$.

\begin{tabular}{ccccc} 
& \multicolumn{5}{c}{ TABLE-3 } \\
& $\begin{array}{c}\text { RESULTS FROM FITTINGS TO FREUNDLICH } \\
\text { ISOTHERM FOR DYE OLIVE BGL }\end{array}$ \\
\hline \multirow{4}{*}{ Dye name } & \multicolumn{4}{c}{ Olive GBL $\mathrm{pH}$} \\
\cline { 2 - 5 } & $\mathrm{C}_{1}$ & $\mathrm{C}_{2}$ & $\mathrm{C}_{2}$ & $\mathrm{C}_{2}$ \\
\cline { 2 - 5 } & 6.60 & 6.60 & 3.32 & 9.97 \\
\hline $\mathrm{K}_{\mathrm{F}}$ & 1.383 & 0.374 & 0.760 & 0.758 \\
$\mathrm{~N}$ & 1.490 & 1.013 & 1.187 & 1.592 \\
$\mathrm{r}^{2}$ & 0.995 & 0.996 & 0.992 & 0.993 \\
$\mathrm{SD}$ & 0.016 & 0.021 & 0.025 & 0.107 \\
\hline
\end{tabular}

The linear plots of $\log \mathrm{q}_{\mathrm{e}}$ and $\log \mathrm{C}_{\mathrm{e}}$ for Freundlich isotherm are shown in Fig. 3.

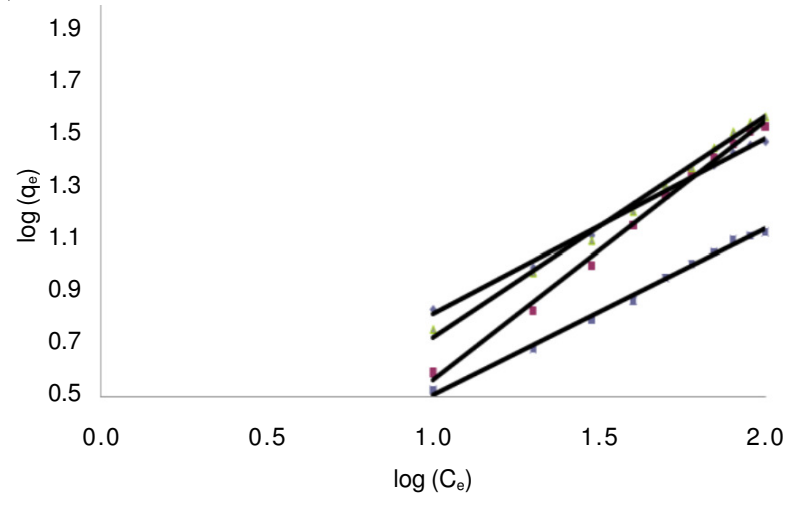

Fig. 3. Freundlich isotherm for dye olive BGL on $\mathrm{C}_{1}$ and $\mathrm{C}_{2}$ at different $\mathrm{pH}$ values

\section{RESULTS AND DISCUSSION}

Granulated activated carbon sample $\mathrm{C}_{1}$ and $\mathrm{C}_{2}$ can be effectively used for the removal of dyes from wastewater by adsorption. The present study shows that there is a decrease in percentage removal of dye per gram with increase in $\mathrm{ppm}$ concentration of the dye. Change in $\mathrm{pH}$ values showed higher adsorption at acidic $\mathrm{pH}$. The dye obeyed Langmuir and Freundlich isotherms. Langmuir isotherm gave a better fit. Carbon sample $\mathrm{C}_{2}$ showed higher adsorption for the dye at acidic $\mathrm{pH}$ and higher ppm concentrations. $\mathrm{C}_{1}$ fared better than $\mathrm{C}_{2}$ at lower ppm concentrations.

At acidic $\mathrm{pH}$ values the adsorbent tends to form an aqua complex to yield a positively charged surface. The ionic dye releases colored dye anions/cations in solution, which in turn is influenced by the solution $\mathrm{pH}$ agents ${ }^{13}$. At acidic $\mathrm{pH}$ there is an increase in $\mathrm{H}^{+}$ions in dye solution. The $\mathrm{OH}^{-}$ions on the adsorbent surface tend to be neutralized by protonation which facilitates the diffusion of dye molecules in the vicinity of the adsorbent. The positively charged surface sites on the adsorbent and the solution thus play a significant role in influencing the capacity of the adsorbent towards dye ions due to electrostatic attraction. Having an excess positive charge on their surface activated carbon shows a greater capacity to adsorb the dye when the solution is made acidic. Lower adsorption at alkaline $\mathrm{pH}$ may have been due to the presence of $\mathrm{OH}^{-}$ions competing with the dye ions for adsorption sites. As the $\mathrm{pH}$ of the system decreases number of negatively charged surface sites increases.

The values of $\mathrm{r}^{2}$ indicate that both adsorption models fitted satisfactorily and suggested monolayer adsorption coverage 
on the outer surface of the adsorbent. Judging by the value of $r^{2}$ Langmuir isotherm gave a better fit. Both samples of activated carbon proved to be reasonably good adsorbents for removing the residual dye olive BGL from waste water.

\section{REFERENCES}

1. A. Chahal, M.Sc. Dissertation, Effects of Waste Water of Dyeing Units on Human Beings, Clothing \& Textiles, Home Science College, Chandigarh, p. 3 (2002).

2. Activated Carbon, http://ewr.cee.vt.edu/environmental/teach/ wtprimer.carbon/sketcar

3. S.P. Mahajan, Pollution Control in Process Industries, Summer Report, 5. IIT, Bombay.
4. M.S. El-Guendi, Water Res., 25, 271 (1991).

5. S. Arora, Waste Treatments given to Dyeing Unit and Textile Industry of Hosiery Cloth of Ludhiana, Dissertation for MSc Clothing \& Textiles, Home Science College, Chandigarh.

6. Whitaker and Hillock, Dyeing with Coal tar Dyestuff, edn. 5, pp. 1-7 (1949).

7. S. Amuda and A.O. Ibrahim, Afr. J. Biotechnol., 5, 1483 (2006).

8. P.P. Pathe, A.K. Biswas, N.N. Rao and S.N. Kaul, Environ. Technol., 26, 313 (2005).

10. Y. Al-Degs, M.A.M. Khraisheh, S.J. Allen and M.N. Ahmad, Water Res., 34, 927 (2000).

11. Z. Aksu and S. Tezer, Process Biochem., 36, 431 (2000).

1. K.R. Ramakrishna and T. Viraraghavan, Water Sci. Technol., 36, 189 (1997). 